\title{
PENGARUH CAPITAL ADEQUACY RATIO, PEMBIAYAAN MUSYARAKAH DAN TINGKAT MARJIN MURABAHAH TERHADAP FINANCING TO DEPOSIT RATIO (STUDI PADA BANK UMUM SYARIAH DI INDONESIA)
}

\author{
Andi Irawan*1, Ridwan Ibrahim ${ }^{* 2}$ \\ ${ }^{1,2}$ Program Studi Akuntansi Fakultas Ekonomi dan Bisnis Universitas Syiah Kuala \\ e-mail: irawanandi38@gmail.com*1, ridwan.ibrahim@ unsyiah.ac.id $^{* 2}$
}

\begin{abstract}
Abstrak
Bank syariah merupakan industri keuangan yang mengandalkan pembiayaan untuk menunjang kinerjanya. Hal ini sering dikaitkan dengan adanya rasio pembiayaan (FDR). Financing to deposit ratio (FDR) sendiri adalah rasio antara besarnya seluruh volume pembiayaan yang disalurkan oleh bank dan jumlah penerimaan dana dari berbagai sumber. Secara garis besar financing to deposit ratio (FDR) juga merupakan rasio keuangan perusahaan perbankan yang berhubungan dengan aspek likuiditas. Populasi dalam penelitian ini adalah semua bank umum syariah di Indonesia yang memenuhi kriteria sebagai objek penelitian, yaitu berjumlah 11 Bank. Teknik pengambilan sampel yang digunakan adalah purposive sampling. Data yang dipakai merupakan laporan keuangan tahunan bank periode tahun 2013 s.d 2015 yang diperoleh dari situs masing- masing bank. Dengan total unit analisis berjumlah 33 laporan keuangan bank umum syariah selama periode 3 tahun. Analisis data yang digunakan dengan uji asumsi klasik dan pengujian hipotesis, penelitian ini menggunakan analisis regresi linear berganda. Hasil penelitian ini menunjukkan bahwa secara simultan keseluruhan variabel independen mempengaruhi variabel dependen. Pengujian secara parsial memperlihatkan hasil bahwa hanya variabel capital adequacy ratio saja yang mempengaruhi financing to deposit ratio. Sedangkan variabel independen lainnya yaitu pembiayaan musyarakah dan tingkat margin murabahah tidak berpengaruh terhadap financing to deposit ratio.
\end{abstract}

Keywords: financing to deposit ratio, capital adequacy ratio, pembiayaan musyarakah, tingkat margin murabahah

\section{Pendahuluan}

\section{Latar Belakang}

Perkembanganjsistem ekonomi Islam di Indonesia ditandai dengan adanya perkembangan lembaga keuangan Islam, hal ini ditunjukan dengan semakin berkembangnya perbankan syariah dalam memobilisasi industri keuangan syariah, sistem perbankan yang baik menjadi faktor penentu perekonomian yang lebih baik pada suatu negara, khususnya Indonesia.

Berdasarkan dari kegiatan operasionalnya bank pada umumnya di bagimenjadi dua yaitu:,Bank Konvension al dan Bank Syariah. Perbedaan antara kedua Bank tersebut terletak pada sistem kerjanya.Bank Konvensionalmemberlakuk an adanya system bunga, sedangkan Bank Syariah tidak memberlakukan adanya sistemi bunga, melainkan sistem bagiihasil. Disisi lainbank syariah menggunakan sistem akad-akad tertentu dalam melakukan beberapa transaksi yang sesuai dengan prinsip syariah, sedangkan bank konvensional tidak memberlakukan hal tersebut. Kinerja suatu bank dilihat dari rasio pembiayaannya, apakah dalam pengelolaan dana yang diberikan oleh nasabah dapat di kelola dengan baik atau tidak.Penelitian ini hanya merujuk pada perbankan syariah saja, khususnya bank umum syariah.Berkaitan dengan masalah pembiayaan maka setiap perbankan syariah selalu dihadapkan dengan sistem penerapan yang harus sesuai dengan prinsip syariah. Pada penelitian ini yang menjadi variabel independen yaitu Capital adequacy ratio, pembiayaan musyarakah dan tingkat marjin murabahah 


\section{Kajian Pustaka dan Kerangka Pemikiran}

\section{Financing to Deposit Ratio}

Financing to Deposit Ratio (FDR ) adalah rasio antara besarnya seluruh volume pembiayaan yang disalurkan oleh bank dan jumlah penerimaan dana dari berbagaisumber(Widiantara, 20 13). Pengertian lainnya Financingto Dep osit Ratio (FDR) adalah rasio keuangan perusahaan perbankan yang berhubungan dengan aspek likuiditas.

Cara untuk menghitung besarnya tingkat pembiayaan, bank syariah menggunakan financing to deposit ratio (FDR) dalam laporan keuangannya dalam bank konvensional disebut dengan istilah LDR

(Loan Deposit Ratio).Perbedaan istilah tersebut tidak mengubah fungsi rasio ini, yaitu rasio keuangan yangdigunakan untuk menguku $r$ sampai sejauh mana pembiayaan yang disalurkanyang bersumber dari dan a pihak ketiga (Muhammad, 2005).

$$
F D R=\frac{\text { Volume Pembiayaan }}{\text { Dana Pihak Ketiga }} \times 100
$$

\section{Capital Adequacy Ratio}

Capital adequacy ratio (CAR) merupakan indicator terhadap kemampuan bank untuk menutupi penurunan aktivanya sebagai akibat dari kerugian kerugian bank yang disebabkan oleh aktiva berisiko.

Capital adequacy ratio juga merupakan rasio kinerja bank yang dapat untuk mengukur kecukupan modal yang dimiliki oleh bank untuk menunjang aktiva yang mengandung atau menghasilkan risiko. Modal merupakan salah satu factor penting dalam rangka pengembangan usaha bisnis dan menampung risiko kerugian, semakin tinggi CAR maka semakin kuat kemampuan bank tersebut untuk menanggung risiko dari setiap kredit/ aktiva produktife yang berisiko (Ruslim, 2012). Jika nilai CAR t inggi(sesuai ketentuan BI 8\%) berarti bank tersebut mampu

membiayai operasional bank, keadaan yang menguntungkan bank tersebut akan memberikan kontribusi yang cukup besar bagi profitabilitas. CAR diukur dengan membagi modal dengan aktiva tertimbang menurut risiko (ATMR) berd asarkan PBI No. 10/15/PBI/2008 tanggal 24 September 2008.

$$
C A R=\frac{\text { Modal Bank }}{A T M R} \times 100 \%
$$

\section{Pembiayaan Musyarakah}

Menurut UU No 21 Tahun 2008 tentang Perbankan Syariah pasal 19 ayat (1) huruf c yang dimaksud dengan "akad Musyarkah" adalah akad kerja sama di antara dua pihak atau lebih untuk semua usaha tertentu yang masing-masing pihak memberikan prosi Diana dengan ketentuan bahwa keuntungan akan dibagi sesuai dengan kesepakatan. Sedangkan kerugian ditanggung sesuai dengan prosi dana masingmasing (aryani, 2014).

\section{Tingkat Marjin Murabahah}

Menurut teori dari Rivai dan Arviyan (2010), proses penentuan tingkat marjin pembiayaan ini ditentukan dengan mempertimbangkan hal-hal antara lain:(i)Beban dana efektif, yaitu beban $\mathrm{d}$ ana operasional yang dikeluarkan bankse telah diperhitungkan dengan cadangan likuiditas wajib minimum yangharus dipelihara olehbank dan seleb ihnya disalurkan dalam berbagai bentuk pembiayaan. (ii) Beban overhead, yaitu seluruh beban dana di luar beban dana yang digunakan dalam menghimpun dana serta beban yang dikeluarkan dalam rangka pengelolaan pembiayaan. (iii) Beban dana,

merupakan penjumlahan beban dana efektifedengan beban dana overhead. (iv) Marjin (laba yang diinginkan), yaitu berupa presentase spread yang dihitung melalui proyeksi jumlah keuntungan yang diperkirakan de ngan jumlah rata-rata outstandingloan dalam satu bulan. (v) Cadangan risiko pembiayaan bermasalah, berupa presentasi premi risiko yang dihitung melalui total penyisihan cadangan penghapusan dengantotal pembiayaan yang dikalsifikasikan. Hal tersebut bertujuan untuk meminimalisir terjadinya risiko pembiayaan dikemudian hari.

Pada dasarnya, marjin merupakan keuntungan yang diperoleh diari hasil kegiatan jual beli yang besarnya telah ditentukan pada awal akad sesuai dengan perjanjian yang telah disepakati. Menurut Karim (2007) pengertian marjin keuntungan yaitu persentasi tertentu yang ditetapkan pertahun perhitungan marjin keuntungan secara harian, maka jumlah hari dalam setahun ditetapkan 360 hari, perhitungan marjin secara bulanan maka setahun ditetapkan 12 bulan. 
Besarnya piutang tergantung pada plafond pembiayaan, yakni jumlah pembiayaan (harga beli ditambah harga pokok) yang tercantum didalam perjanjian pembiayaan.

Untuk mendapatkan hasil margin digunakan rumus:

$$
\begin{aligned}
& \text { Presentase Margin (Murabahah) } \\
& =\frac{\text { Cost Recorvery }+ \text { Keuntungan }}{\text { Harga Beli Bank }} \times 100
\end{aligned}
$$

\section{Penelitian Terdahulu}

Penelitian yang berkaitan dengan Capital adequacy ratio, pembiayaan musyarakah, tingkat marjin murabahah dan financing to deposit ratio pada perbankan syariah telah diteliti sebelumnya. Beberapa penelitian tersebut seperti penelitian Sri Handayani (2016). Hasil penelitian menunjukkan variable CAR, BOPO, ROA dan NIM secara simultan tidak berpengaruhn terhadap FDR PT. BPRS Bhakti Sumekar Sumenep karena Sig. $>0,05$ dan nilai Fhitung < Ftabel. Setelah menghapus beberapa variable $b$ ebas yang dianggap menyebabkan terjadi multikolinearitas dalam penelitian ini yaitu variabel BOPO dan ROA, maka variable CAR dan NIM secara simultanb erpengaruhpositifetidak signifikan terhadap FDR.

Dinna Nurhadiyanti (2014) dalam penelitiannya mengemukakan bahwa Penelitiannya tersebut bertujuan untuk (1) mengetahui tingkat perkembangan pembiayaan musyarakah (2) mengetahui tingkat financing to deposit ratio (3) seberapa besar pengaruh pembiayaan musyarakah terhadap FDR pada PT. BPRS Alwadi'ah.

Metode yang digunakan dalam penelitiannya adalah metode deskriptif analisis verivikatif dengan pendekatan kuantitatif. Teknik pengumpulan data dilakukan melalui data primer yaitu data keuangan yang diperoleh langsung dari PT. BPRS Al Wadiah Tasikmalaya dan data sekunder yaitu diperoleh dari literature dan buku-buku.Alat analisis yang digunakan adalah analisis regresi linier sederhana, korelasi pearson product moment, koefisien determinasi dan uji hipotesis (uji t). Hasil penelitian statistic uji hipotesis menunjukan bahwa pembiayaan musyarakah tidak berpengaruh secara signifikan terhadap financing to deposit ratio.Tetapi pembiayaan musyarakah memiliki peranan atau hubungan yang searah terhadap financing to deposit ratio yaitu sebesar $3.96 \%$ dan sisanya $96.04 \%$ dipengaruhi oleh faktor lain yang tidak diteliti pada penyusunan ini.

Penelitian dari Nareswari Saputro (2014) yang menjelaskan tentangpengaruh tingkat marjin murabah ah terhadap financingto deposit ratio dan Non Performing financing pada Bank Syariah Indonesia pada periode 2010 s.d 2012.

Penelitian ini menggunakan pendekatan kuantitatif dengan menggunakan analisis jalur dengan tiga jenis variabel, yaitu tingkat marjin murabahah sebagai variabel eksogen, financing to deposit ratiosebagai variable endogen intervensi dan Non Performing financing sebagai variable endogen. Industri Perbankan Syariah digunakan sebagai sampel dalam penelitian ini, yang terdiri dari Bank Umum Syariah (BUS) dan Unit Usaha Syariah Bank Konvensional (UUS).

Selanjutnya, penelitian ini menggunakan data sekunder yang dilakukan dengan caramengumpulkan laporan keuangan bulananselama tiga tahun. Hasil penelitian menunjukkan bahwa tingkat margin murabahah berpengaruh negatif terhadap Financing to deposit Rasio (FDR) Perbankan Syariah di Indonesia. Sementara itu, Tingkat marjin murabahah berpengaruh positifesecara signifikan terhadap non performing financing (NPF). Hal ini juga terjadi pada efek dari financing to deposito ratio (FDR) terhadapnonperfor ming financing (NPF) Bank Syariah di Indonesia periode 2010 s.d 2012.

\section{Kerangka Pemikiran}

Penelitian ini bertujuan untuk menguji pengaruh variable independen terhadap variable dependen yang financing to deposit ratio. Varibel independen dalam penelitian ini antara lain adalah :capital adequacy ratio, pembiayaan musyarakah, dan tingkat marjin murabahah.

\section{Capital Adequacy Ratio Terhadap Financing To Deposit Ratio}

Hubungan antara CAR dengan FDR sangat erat sekali dikarenakan besarnya tingkat CAR mempengaruhi tingkat FDR. apabila CAR meningkat maka FDR juga meningkat, begitu juga sebaliknya. Penelitian Prihatiningsih (2012)memberikan hasil bahwa CAR ber pengaruh negative terhadap FDR bank syariah. Penelitian ini tidak sejalan deng an penelitian dari Aziz (2011) danAmria ni (2012) yang 
menyatakan bahwa CAR berpengaruh positif terhadap

FDR bank syariah dan konvensional.

\section{Pembiayaan Musyarakah Terhadap Financing To Deposit Ratio}

Hasil penelitian Dinna Nurhadiyanti (2014) menyatakan bahwa Pembiayaan Musyarakah tidak berpengaruh secara signifikan terhadap financing to deposit Ratio.Tetapi pembiayaan musyarakah memiliki peranan atau hubungan yang searah terhadap financing to deposit ratio yaitu sebesar $3.96 \%$ dan sisanya $96.04 \%$ dipengaruhi oleh faktor lain yang tidak diteliti pada penyusunannya tersebut. Namun penelitian Elza Mauduhatul Zahroh (2012) yang menyatakan berbeda, bahwa Pembiayaan bagi hasil (mudharabah dan musyarakah) berpengaruhtidak signifikan terhadap financing to deposit ratio (FDR), hal tersebut menjelaskan bahwa pembiayaan musyarakah memiliki hubungan dengan financing to deposit ratio meski tidak signifikan.Dengan hasil penelitian tersebut maka mengindikasikan bahwa apabila pembiayaan musyarakah meningkat maka financing to deposit ratio juga meningkat.

\section{Tingkat Marjin Murabahah Terhadap Financing To Deposit Ratio}

Menurut Muhamad (2005:143) tingkat marjin keuntungan berpengaruh terhadap jumlah permintaan pembiayaan syariah. Bila tingkat marjin keuntungan lebih rendah dari pada rata-rata suku bunga perbankan nasional, maka pembiayaan syariah semakin kompetitif sehingga jumlah pembiayaan yang disalurkan oleh bank syariah akan meningkat. Pengaruh ini terjadi karena tingkat marjin berhubungan dengan minat masyarakat untuk melakukan pembiayaan di bank syariah. Ketika tingkat marjin naik maka minat masyarakat untuk meminjam pembiayaan semakin berkurang, hal itu terjadi karena masyarakat dihadapkan dengan jumlah pembayaran pembiayaan ditambah marjin yang tinggi sehingga tingkat marjin yang tinggi ini akan memberatkan nasabah sehingga nasabah akan beralih ke bank lain yang lebih menguntungkan. Hal ini sejalan dengan apa yang telah dipaparkan oleh Jihad dan Hosen (2009:110). Penelitian yang dilakukan oleh Nareswari Saputro (2014) menyatakan bahwa Tingkat Margin Murabahah mempengaruhi financing to deposit ratio perbankan sya riah di Indonesia periode 2010 s.d
2012.

\section{Penelitian Hipotesis}

Berdasarkan teori yang digunakandankerangka pemikiran, makah ipotesis dalam penelitian ini adalah sebagai berikut:

H1 : Capital adequacy ratio, pembiayaan Musyarakah dan tingkat marjin Murabahah berpengaruh terhadap Financing to deposit ratio bank umum syariah di Indonesia.

$\mathrm{H} 2$ : Capital adequacy ratio berpengaruh terhadap financing to deposit ratio bank umum syariah di Indonesia

H3:Pembiayaan musyarakah tidak berpengaruh terhadap financ ing todeposit ratio bank umum s yariah di Indonesia

H4 : Tingkat marjin murabahah tidak berpengaruh terhadap financ ing todeposit ratio bank umum s yariah di Indonesia

\section{Metode Penelitian \\ Desain Penelitian}

Sekaran (2013:155) menyebutkan bahwa desain penelitian adalah program kerja dari penelitian meliputi hal-hal yang akan dilakukan peneliti dimulai dari membangun hipotesis dan implikasinya secara operasional sampai ke analisis data. Desain penelitian meliputi serangkaian pilihan yang sangat bergantung pada seberapa hati-hati peneliti memilih berbagai alternatif desain yang tepat untuk memenuhi tujuan tertentu dari penelitian

Populasi dalam penelitian ini adalah industry bank syariah yangterdiri dari Bank Umum Syariah di Indonesia tahun 2013 s.d 2015. Sampel pada penelitian ini yaitu menggunakan metode purposive sampling.

Sampel pada penelitian ini dapat dilihat dari tabel berikut ini:

Tabel 3.1

Perolehan Sampel Penelitian

\begin{tabular}{|l|l|}
\hline $\begin{array}{l}\text { Jumlah bank umum syariah di } \\
\text { Indonesia }\end{array}$ & 12 \\
\hline $\begin{array}{l}\text { Bank umum syariah yang tidak menerbitkan } \\
\text { laporan tahunan pada periode pengamatan } \\
\text { yaitu Bank Tabungan Pensiunan Nasional } \\
\text { Syariah }\end{array}$ & $(1)$ \\
\hline Total Bank & 11 \\
\hline Total Unit Analisis (total bank x 3 tahun) & 33 \\
\hline
\end{tabular}


Berdasarkan table di atas dapat d iketahui bahwa sampel penelitian yang memenuhi kriteria berjumlah 11 bank. Sehingga unit analisis penelitian berjumlah 33 laporan keuangan tahunan bank syariah yang terdiri empat periode pengamatan yaitu tahun 2013 s.d 2015. Perbankan syariah yang tidak memenuhi kriteria ialah Bank Tabungan Pensiunan Nasional Syariah (BTPNS) dan Maybank Syariah.

Jenis data yang digunakan dalam penelitian ini adalah data sekunde r,sehingga metode pengumpulan menggu nakan cara non participant observation, yaitu mengumpulkan data yang telah tersedia pada situs resmi masing-masing Bank Umum Syariah.

Sekaran (2013:162) data sekunder mengacu pada informasi yang dikumpulkan oleh seseorang dan bukan peneliti yang melakukan studi mutakhir. Data sekunder dimaksud dalam penelitian ini yaitu data informasi keuangan atau laporan keuangan tahunan bank umum syariah di Indonesia yang diperloeh dari situs resmi Bank Indonesia dan situs masing-masing bank umum syariah di Indonesia dalam periode 2013 s.d 2015 .

\section{Operasional Variabel \\ Variabel Dependen}

Variabel dependen dalam peneliti an ini adalah financing to deposit ratio Bank Umum Syariah yaitu persentase rata- rata yang menunjukkan hasil dari perbandingan antara jumlah volume pembiayaan terhadap jumlah dana pihak ketiga pada Bank Umum Syariah (BUS), selama periode januari 2013 s.d desember 2015.

\section{Variabel Independen}

Variabel independen adalah variable bebas yang mempengaruhi variable terikat atau variable dependen. Dalam penelitian ini, variabel independen terbagi atas tiga, yaitu capital adequacy ratio, pembiayaan musyarakah dan tingkat marjin murabahah.

\section{Metode Analisis dan Rancangan Pengujan Hipotesis \\ Metode Analisis}

Metode analisis yang digunakan dalam penelitian ini adalah analisisregres i regresi linear berganda digunakan untu $\mathrm{k}$ mengetahui pengaruh antar variabel dependen dan independen yaitu
Pengaruh Capital Adequacy Ratio, Pembiayaan Musyarakah dan Tingkat Marjin Murabahah terhadap Financing to Deposit Ratio. Adapun persamaannya sebagai berikut:

$$
\mathbf{Y}=\alpha+\beta_{1} \mathbf{X}_{1}+\beta_{2} \mathbf{X}_{2}+\beta_{3} \mathbf{X}_{3}+\varepsilon
$$

Keterangan :

$\begin{array}{ll}\mathrm{Y} & : \text { Financing toDeposit Ratio } \\ \alpha & \text { : Konstanta } \\ \beta & \text { : Koefisien Regresi } \\ \mathrm{X} 1 & \text { : Capital Adequacy Ratio } \\ \mathrm{X} 2 & \text { : Pembiayaan Musyarakah } \\ \mathrm{X} 3 & \text { : Tingkat Marjin Murabahah } \\ \varepsilon & : \text { Standar Error }\end{array}$

\section{Hasil dan Pembahasan}

\section{Hasil Penelitian}

\section{Statistik Deskriptif}

Statistik deskriptif memberikan gambaran mengenai suatu data yang dilihat dari nilai terendah, nilai tertinggi, nilai rata-rata dan standar deviasi. Menurut Sugiyono (2013:206) statistic deskriptife adalah statistic yang digunakan untuk menganalisa data dengan cara mendeskripsikan atau menggambarkan data yang telah terkum pul sebagaimana adanya tanpa bermaksud membuat kesimpulan yang berlaku untuk umum. Hasil analisis statisitik deskriptifedalam penelitian ini dapat dilihat pada table 4.1 dibawah ini:

Tabel 4.1

Statistik Deskriptif

\begin{tabular}{|l|r|r|r|r|r|}
\hline & $\mathrm{N}$ & Min & Max & Mean & $\begin{array}{r}\text { Std. } \\
\text { Deviati } \\
\text { o n }\end{array}$ \\
\hline FDR & 33 & 81,99 & 157,77 & 96,9512 & $\begin{array}{r}16,3942 \\
0\end{array}$ \\
\hline CAR & 33 & 11,10 & 59,61 & 20,5891 & $\begin{array}{r}10,9991 \\
0\end{array}$ \\
\hline $\begin{array}{l}\text { PMUS } \\
\text { YARA KAH }\end{array}$ & 33 & 5,87 & 53,37 & 24,7676 & $\begin{array}{r}11,9346 \\
7\end{array}$ \\
\hline $\begin{array}{l}\text { TMMU } \\
\text { RABA HAH }\end{array}$ & 33 & 10,37 & 47,38 & 26,2588 & 9,71186 \\
\hline $\begin{array}{l}\text { Valid N } \\
\text { (listwis e) }\end{array}$ & 33 & & & & \\
\hline
\end{tabular}

Sumber: Output hasil SPSS 
Berdasarkan tabel 4.1 diatas dapat dilihat nilai terendah, nilai tetinggi, nilai rata-rata, dan nilai standar deviasi dari beberapa variabel, dengan jumlah 11 bank umum syariah yang menjadi sampel penelitian. Variabel dependen dalam penelitian ini adalah financing to deposit ratio. Pada tabel 4.1 ditunjukkan bahwa nilai rata-rata dari financing to deposit ratio yaitu sebesar 96,9512 Hal ini mengindikasikan bahwa rata-rata bank umum syariah di indonesia sampel yang diteliti telah memperoleh tingkat rasio pembiayaan perusahaannya sebesar 96,9512 atau dibulatkan $97 \%$ dari maksimum rasio pembiayaan yang telah ditetapkan yaitu sebesar $110 \%$.

Variabel independen yang pertama (X1) adalah capital adequacy ratio. Nilai terendah dari variabel ini menunjukkan 11,10, hal ini bermakna bahwa tingkat kemampuan bank umum syariah dalam menampung risiko kerugian yang kemungkinan dihadapi oleh bank, dalam presentase titik terkecilnya yaitu 11,10\%. Sedangkan nilai tertingginya sebesar 59,61 yang mengindikasikan bahwa puncak risiko yang dapat ditanggung oleh pihak bank umum syariah mencapai $59,60 \%$. Variabel ini memiliki nilai rata-rata 20,5891 yang berarti bank umum syariah di Indonesia rata-rata hanya mampu menampung risiko pada titik presentase tersebut, dan nilai standar deviasi captal adequacy ratio yaitu sebesar 10,99910 yang lebih kecil dari nilai rata-rata. Hal ini menunjukkan bahwa variasi data capital adequacy ratio terhadap nilai rata-ratanya rendah atau disebut juga homogen.

Variabel independen yang kedua (X2) adalah pembiayaan musyarakah. Nilai terendah dari variabel ini menunjukkan 5,87 hal ini bermakna bahwa pihak bank umum syariah dalam memperoleh pembiayaan musyarakah hanya $5,87 \%$. Sedangkan nilai tertingginya sebesar 53,37 yang mengindikasikan bahwa puncak bank umum syariah dalam memperoleh pembiayaan musyarakah mencapai 53,37\%. Variabel ini memiliki nilai rata- rata 24,7676 yang berarti bank umum syariah di Indonesia rata-rata hanya mampu memperoleh pembiayaan dalam presentase tersebut, tetapi hal ini mengindikasikan bahwa pembiayaan musyarakah pada bank umum syariah sudah terbilang baik. Nilai standar deviasi pembiayaan musyarakah yaitu sebesar 11,93467 yang lebih kecil dari nilai ratarata. Hal ini menunjukkan bahwa variasi data pembiayaan musyarakah terhadap nilai rata-ratanya rendah atau disebut juga homogen.
Variabel independen yang ketiga (X3) adalah tingkat margin murabahah. Nilai terendah dari variabel ini menunjukkan 10,37, hal ini bermakna bahwa pihak bank umum syariah dalam menentukan tingkat margin murabahah sebesar $10,37 \%$. Sedangkan nilai tertingginya sebesar 47,38 yang mengindikasikan bahwa penentuan tingkat margin murabahah yaitu mencapai $47,38 \%$. Variabel ini memiliki nilai rata- rata 26,2588 yang berarti bank umum syariah di Indonesia rata-rata dalam menentukan tingkat margin murabahah tidak terlalu tinggi, hal ini mengindikasikan bahwa tingkat margin murabahah masih dalam batas kewajaran. dan nilai standar deviasi tingkat margin murabahah yaitu sebesar 9,71186 yang lebih kecil dari nilai rata-rata. Hal ini menunjukkan bahwa variasi data tingkat margin murabahah terhadap nilai rata- ratanya rendah atau disebut juga homogen.

\section{Hasil Pengujian Asumsi Klasik Uji Normalitas}

Uji normalitas merupakan uji asu msi klasik yang pertama Tujuan uji normalitas yaitu untuk menguji apakah model regresi memiliki distribusi normal atau tidak (Ghozali,2006). Model regresi yang baik adalah distribusi data normal atau mendekati normal Dalam penelitian ini untuk menguji distribusi data digunakan uji statistic non-parametrik OneSample Kolmogorov Smirnov. Hasil pengujian nor malitas dapat dilihat padaTabel 4.2.

Tabel 4.2

Uji Normalitas

\begin{tabular}{|c|c|c|}
\hline & & $\begin{array}{c}\text { Unstandardize } \\
\text { d Residual }\end{array}$ \\
\hline $\mathrm{N}$ & & 33 \\
\hline Normal & Mean &, 0000000 \\
\hline Parameters ${ }^{\mathrm{a}}$ & $\begin{array}{l}\text { Std. } \\
\text { Deviation }\end{array}$ & 9,02870079 \\
\hline \begin{tabular}{|l}
, $\mathrm{O}$ \\
Most
\end{tabular} & Absolute &, 102 \\
\hline Extreme & Positive &, 102 \\
\hline Differences & Negative &,- 088 \\
\hline Test Statistic & &, 102 \\
\hline Asymp. Sig. & ailed) &, $200^{\mathrm{c}, \mathrm{u}}$ \\
\hline $\begin{array}{l}\text { a. Test distrib } \\
\text { b. Calculated } \\
\text { c. Lilliefors Si }\end{array}$ & $\begin{array}{l}\text { is Normal. } \\
\text { data. }\end{array}$ & \\
\hline
\end{tabular}

Sumber: Output hasil SPSS 
Hasil pengujian pada Tabel 4.2 dapat dilihat pengujian terhadap variabel- variabel yang akan diteliti menunjukkan bahwa besarnya nilai Kolomogorov- Smirnov adalah 0,200 dengan nilai signifkansi diatas $0,05(5 \%)$. Hasil ini menunjukkan bahwa data terdistribusi secara normal.

\section{Uji Multikolineritas}

Uji multikolinearitas digunakan untuk menguji apakah pada model regresi ditemukan adanya kolerasi antara variable indipenden. Model regresi yang baik adalah tidak terjadi korelasi di antara variable bebas. Untuk mengetahui ada atau tidaknya gejala multikolinearitas antara lain dengan melihat nilai Variance Inflation Factor (VIF) dan Tolerance, apabila nilai VIF kurang dari 10 dan Tolerance lebih dari 0,1 , maka dinyatakan tidak terjadi multikolinearitas (Priyatno: 2014, dalam Ghozali: 2001)

Tabel 4.3

Uji Multikolineritas

\begin{tabular}{|c|c|c|c|c|c|c|c|c|}
\hline & \multirow{2}{*}{ Model } & \multicolumn{2}{|c|}{$\begin{array}{c}\text { Unstandardiz ed } \\
\text { Coefficients } \\
\end{array}$} & \multirow{2}{*}{$\begin{array}{c}\text { Stan dardi zed } \\
\text { Coefficients } \\
\text { Beta } \\
\end{array}$} & \multirow{2}{*}{$\mathrm{t}$} & \multirow{2}{*}{ Sig. } & \multicolumn{2}{|c|}{ Collinearity Statistics } \\
\hline & & B & $\begin{array}{c}\text { Std. } \\
\text { Error }\end{array}$ & & & & Tolerance & VIF \\
\hline 1 & (Cons tant) & 66,487 & 7,403 & & 8,981 & $\overline{, 000}$ & & \\
\hline & CAR & 1,249 & ,154 & 838 & 8,112 &, 000 & ,980 & 1,020 \\
\hline & PMUS YARA KAH &, 017 & , 145 &, 012 &, 116 & ,908 & ,941 & 1,062 \\
\hline & TMM URAB AHAH & , 165 & ,178 & ,098 & ,928 & ,361 & ,944 & 1,060 \\
\hline
\end{tabular}

Sumber: Output hasil SPSS

Hasil uji multikolonieritas berdas arkan Tabel 4.4 menunjukkan hasil bahwa tidak ada variable independen yang memiliki nilai tolerance kurang dari 0,10 . Hasil perhitungan VIF juga menunjukkan hal yang sama bahwa tidak ada variable independen yang memiliki nilai VIF lebih besar dari 10. Dengan demikian, dapat disimpulkan ba hwa tidak ada multikolonieritas yang terjadi antar variable independen dalam model regresi.

\section{Uji Autokorelasi}

Autokorelasi adalah korelasi antara variable itu sendiri pada pengamatan yang berbeda waktu atau in dividu. Uji Autokorelasi bertujuan untuk menguji apakah dalam model regresi berganda ada korelasi antara kesalahan pengganggu pada periode $t$ dengan kesalahan pada periode $\mathrm{t}$ dengan kesalahan pada periode t- 1 (sebelumnya). Jika terjadi korelasi maka dikatakan ada problem autokorelasi. Model korelasi yang baik adalah korelasi yang bebas dari autokorelasi. Deteksi adanya autokorelasi dapat dilihat dari besaran nilai Asymp. Sig. (2-tailed). Secara umum dapat diambil patokan:

1. Jika signifikansi (5\%) < Asymp. Sig. (2-tailed) maka tidak terdapat autokorelasi positif
2. Jika signifikansi $(5 \%)>$ Asymp. Sig. (2-tailed) maka terdapat autokorelasi positif

Tabel 4.4

Uji Autokorelasi

\begin{tabular}{|l|r|}
\hline & Unstandardized Residual \\
\hline Test Value &, 76032 \\
Cases $<$ Test Value & 16 \\
Cases $>=$ Test Value & 17 \\
Total Cases & 33 \\
Number of Runs & 16 \\
Z & -349 \\
Asymp. Sig. (2-tailed) &, 727 \\
\hline
\end{tabular}

Sumber: Output hasil SPSS

Berdasarkan hasil pengujian dengan mengggunakan uji runtun (runs test) pada tabel 4.5 menunjukkan bahwa pada tingkat signifikansi 5\% dengan Asymp. Sig. (2-tailed) sebesar 0,727 atau 7,27 $\%$ menunjukkan bahwa nilai tersebut lebih besar dibandingkan nilai sig, hal ini mengindikasikan bahwa tidak terdapat adanya autokorelasi.

\section{Uji Heteroskedastisitas}

Uji heteroskedastisitas bertujuan untuk menguji apakah dalam model regresi terjadi ketidaksamaan variable dari residual satu pengamatan ke pengamatan yang lain. Jika varian dari residual satu pengamatan 
ke pengamatan yang lain tetap, maka disebut homoskedastisitas dan jika berbeda disebut heteroskedastisitas. Model yang baik adalah tidak terjadi heteroskedastisitas. Dasar pengambilan keputusannya, apabila ada pola tertentu seperti titik yang membentuk suatu pola tertentu yang teratur (bergelombang, melebar kemudian menyempit) maka telah terjadi heteroskdastisitas. Jika tidak ada pola tertentu, serta titi ktitik menyebar di atas dan dibawah angka 0 pada sumbu $Y$, maka tidak terjadi heteroskedastisitas.

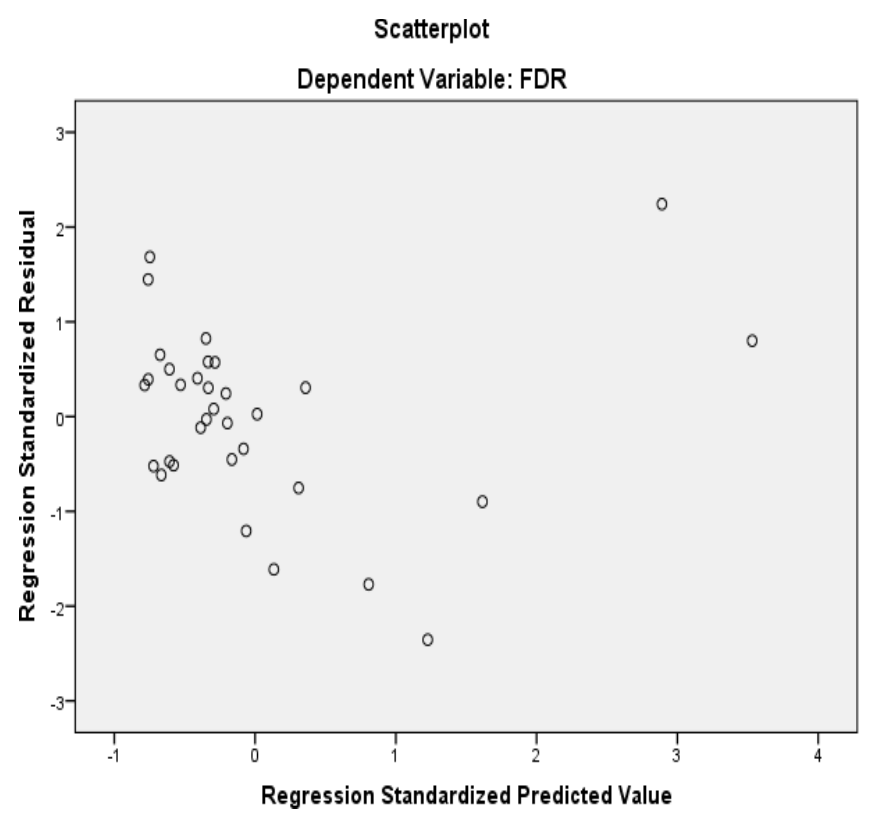

Sumber: Output hasil SPSS

\section{Gambar 4.1 Uji Heteroskedastisitas}

Analisis dari grafik di atas, terlihat titik-titik menyebar secara acak, tidak membentuk sebuah pola tertentu y ang jelas, serta tersebar baik di atas maupun di bawah angka 0 pada sumbu Y. Hal ini berarti tidak terjadi heteroskedastisitas pada model regresi. $\mathrm{S}$ ehingga model regresi layak dipakaiuntu prediksi Y berdasarkan masukan X1, X 2 dan X3

\section{Hasil Pengujian Statistik \\ Uji Statistik F (simultan)}

Uji $\mathrm{F}$ digunakan untuk mengetahui apakah variable independent yang digunakan dalam model regresi yaitu Capital Adequacy Ratio, Pembiayaan musyarakah dan Tingkat Margin Murabahah mampu menjelaskan variable dependennya, yaitu Financing to Deposit Ratio. Hasilyang diperoleh dari Uji F yang dilakukan dengan menggunakan IBM SPSS Statistics Version 22 dapat dilihat dari table ANOVA. Hasil F test menunjukan variable independent secara barsama-sama berpengaruh terhadap variable dependen jika pvalue (yang terd apat pada kolom signifikan) lebihkecil d ari level of significant yaitu 5\%.

Tabel 4.5

Uji Statistik F (Simultan)

\begin{tabular}{|c|c|c|c|c|c|c|}
\hline \multicolumn{2}{|c|}{ Model } & $\begin{array}{l}\text { Sum of } \\
\text { Squares }\end{array}$ & $\mathrm{df}$ & $\begin{array}{c}\text { Mean } \\
\text { Square }\end{array}$ & $\mathrm{F}$ & Sig. \\
\hline \multirow{3}{*}{\multicolumn{2}{|c|}{$\begin{array}{ll}1 & \text { Regressio } \\
& \mathrm{n} \\
& \text { Residual } \\
& \text { Total } \\
\end{array}$}} & 5992,074 & 3 & 1997,358 & 22,205 &, 000 \\
\hline & & 2608,558 & 29 & 89,950 & & \\
\hline & & 8600,632 & 32 & & & \\
\hline
\end{tabular}

Analisis dari table di atas, nilai $p$-value adalah sebesar 0,000 . Ini berarti menunjukan bahwa nilai $p$ value tersebut lebih kecil dari level of significant yang telah ditentukan sebesar 5\%. Berarti capital adequacy ratio, pembiayaan musyarakah dan tingkat margin murabahah secara simultan berpengaruh positif terhadap financing to deposit ratio.

\section{Uji Signifikan Parameter Individual (Parsial)}

Uji t digunakan untuk menunjukan seberapa jauh pengaruh satu variable penjelas atau independen secara individual dalam menerangkan variasi variable dependen. Ini berarti me njelaskan capital adequacy ratio, pembiayaan musyarakah dan tingkat margin murabahah secara terpisah dapat mempengaruhi financing to depost ratio. Hasil uji t yang dilakukan dengan menggunakan IBM SPSS Statistics Version 22 dapat dilihat pada table Coefficients, hubungan dari masing-masing variable independen terhadap variable dependen dapat dilihat dari nilai $p$-value. Nilai $p$-value yang memenuhi standar adalah lebih kecil dari $5 \%$. 
Tabel 4.6

Uji Signifikan Parameter Individual (Parsial)

\begin{tabular}{|c|c|c|c|c|c|c|c|}
\hline \multirow[t]{2}{*}{ Model } & \multicolumn{2}{|c|}{ Unstandardized Coefficients } & \multirow{2}{*}{$\begin{array}{l}\begin{array}{c}\text { Stan dardi zed } \\
\text { Coef ficien } \\
\text { ts }\end{array} \\
\text { Beta }\end{array}$} & \multirow[t]{2}{*}{$\mathrm{t}$} & \multirow[t]{2}{*}{ Sig. } & \multicolumn{2}{|c|}{ Collinearity Statistics } \\
\hline & B & $\begin{array}{l}\text { Std. } \\
\text { Error }\end{array}$ & & & & Tolerance & VIF \\
\hline (Constant) & 66,487 & 7,403 & & 8,981 &, 000 & & \\
\hline CAR & 1,249 & ,154 & ,838 & 8,112 & 000 & 980 & 1,020 \\
\hline PMUSYARA KAH & ,017 & ,145 & ,012 & ,116 & ,908 & ,941 & 1,062 \\
\hline 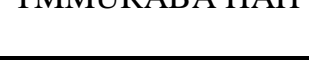 &, 165 &, 178 & ,098 & ,928 &, 361 & 944 & 1,060 \\
\hline
\end{tabular}

Analisis dari table di atas, capital adequacy ratio diketahui bahwa nilai $p$-value $<\alpha(0,000<0,05)$ yang artinya 0,000 lebih kecil dari pada0,05, yang berarti signifikan. Dengan demikian dapat disimpulkan bahwa capital adequacy ratio secara parsial berpengaruh positif terhadap financing to deposit ratio. Sedangkan untuk pembiay aan musyarakah diketahui bahwa nilai $p$-value $>\alpha(0,908>$ $0,05)$ yang artinya 0,908 lebih besar dar i pada 0,05 ,yang berarti tidak signifikan. Dengan demikian dapat disimpulkan bahwa pembiayaan musyarakah secara pa rsial tidak berpengaruh positif terhadap financing to deposit ratio dan untuk tingkat margin murabahah diketahui bahwa nilai $p$-value> $\alpha(0,361>0,05)$ yang artinya 0,361 lebih besar dar ipada 0,05 , yang berarti tidak signifikan. Dengan demikian dapat disimpulkan bah wa pembiayaan musyarakah secara parsi al tidak berpengaruh positif terhadap financing to deposit ratio.

\section{Hasil Pengujian Hipotesis}

\section{Uji Koofisien Determinasi}

Koofisien determinasi (R2) digun akan untuk mengukur seberapa jauh kemampuan model dalam menerangkan variasi variable dependen. Koofisien determinasi adalah diantara nol dan satu, jika nilai kecil atau mendekati nol maka variasi variable dependen amat ter batas. Sedangkan jika nilai besar atau mendekati satu maka hamper semu a informasi yang dibutuhkan untuk memprediksi variable dependen. Koofisie $\mathrm{n}$ determinasi ini digunakan untuk mengetahui besarnya dukungan variable independen terhadap variabel dependen dalam satuan persen.
Tabel 4.7

Uji Koofisien Determinasi

\begin{tabular}{l|r|r|r|r|r|}
$\begin{array}{l}\text { Mod } \\
\text { el }\end{array}$ & $\mathrm{R}$ & $\begin{array}{c}\mathrm{R} \\
\text { Squa } \\
\text { re }\end{array}$ & $\begin{array}{c}\text { Adjusted } \\
\text { R Square }\end{array}$ & $\begin{array}{c}\text { Std. } \\
\text { Error of } \\
\text { the } \\
\text { Estimate }\end{array}$ & $\begin{array}{r}\text { Durbin- } \\
\text { Watson }\end{array}$ \\
\hline 1 &, $835^{\mathrm{a}}$ &, 697 &, 665 & 9,48421 & 2,056 \\
\hline
\end{tabular}
T. Predictors: (Constant),
TMMURABAHAH, CAR,
PMUSYARAKAH
b. Dependent Variable: FDR

Sumber: Output hasil SPSS

Analisis dari table diatas, besarnya nilai adjusted R2 sebesar 0,665yang berarti dukungan capital adequacy ratio. pembiayaan musyarakah dan tingkat margin murabahah terhadap fina ncing to deposit ratio sebesar $66,5 \%$. Hal tersebut menunjukan bahwa $33,5 \%$ dari sisa dukungan tersebut merupakan variable lain yang tidak mas uk dalam model penelitian yang mempe ngaruhi FDR.

\section{Analisis Regresi Berganda}

Analisis regresi merupakan suatu metode yang digunakan untuk menganalisis hubungan antara variabel. Hubungan terikat $\mathrm{Y}$ dengan satu atau lebih variable bebas $(\mathrm{X} 1, \mathrm{X} 2, \ldots \mathrm{Xn})$. Untuk dapat menganalisis variabel independen terhadap variable dependen. Dalam penelitian ini regresi berganda digunakan untuk menge tahui kelinieran pengaruh secara bersamaan antara variable capital adequacy ratio, pembiayaan musyarakah dan tingkat margin murabahah terhadap financing to deposit ratio. Dari hasil uji statistic di atas, maka diperoleh model $r$ egresi sebagai berikut 


$$
\mathrm{y}=66,487+1,249 \times 1+0,017 \times 2+0,165+7,403
$$

\section{Keterangan :}

$$
\begin{array}{ll}
\mathrm{y} & =\text { Financing to Deposit Ratio } \\
\alpha & =\text { Konstanta } \\
\mathrm{X} 1 & =\text { Capital Adequacy Ratio (CAR) } \\
\mathrm{X} 2 & =\text { Pembiayaan Musyarakah } \\
\mathrm{X} 3 & =\text { Tingkat Margin Murabahah } \\
\varepsilon & =\text { Standar Error }
\end{array}
$$

\section{Pembahasan Hasil Pengujian Hipotesis}

Berdasarkan hasil regresi linear berganda yang telah diperoleh dalam penelitian ini, maka berikut akan dibahas pengaruh variabel independen yaitu capital adequacy ratio, pembiayaan musyarakah dan tingkat margin murabahah terhadap variabel dependent yaitu financing to deposit ratio

\section{Pengaruh Capital Adequacy Ratio, pembiayaan musyarakah dan Tingkat Margin Murabahah Terhadap Financing To Deposit Ratio}

Berdasarkan hasil pengujian statistik $F$ diperoleh nilai signifikansi sebesar 0,000 dan lebih kecil dari taraf signifikan 0,05 (5\%). Maka, dapat disimpulkan bahwa hipotesis pertama $\left(\mathrm{H}_{1}\right)$ diterima, sehingga variabel independensi capital adequacy ratio, pembiayaan musyarakah dan tingkat margin murabahah secara bersama-sama berpengaruh signifikan terhadap financing to deposit ratio.

\section{Pengaruh Capital Adequacy Ratio Terhadap Financing to Deposit Ratio}

Variabel capital adequacy ratio $\left(\mathrm{X}_{1}\right)$ memiliki nilai t 8,112 dengan tingkat signifikansi 0,000 lebih kecil dari taraf signifikansi 0,05 (5\%). Hal tersebut menunjukkan bahwa capital adequacy ratio berpengaruh signifikan terhadap financing to deposit ratio. Dengan demikian hipotesis kedua $\left(\mathrm{H}_{2}\right)$ diterima. Hal ini menunjukkan bahwa hasil penelitian ini mendukung teori financing to deposit ratio yang menyatakan capital adequacy ratio memiliki peran yang penting karena dengan tingkat capital adequacy ratio yang tinggi maka berpengaruh besar terhadap nasabah dalam memberikan pendanaan kepada pihak bank.
Hasil penelitian ini sejalan dengan penelitian Aziz (2011) dan Amriani (2012) yang menyatakan bahwa capital adequacy ratio berpengaruh positif terhadap financing to deposit ratio bank syariah dan konvensional. Penelitian ini dapat diartikan bahwa capital adequacy ratio memang sangat berpengaruh besar terhadap perkembangan bank umum syariah, apabila tingkat capital adequacy ratio tinggi, maka mengindikasikan bahwa bank telah siap menanggung kerugian yang kemungkinan dialami. Namun hasil penelitian ini berbeda dengan penelitian yang dilakukan oleh Sri Handayani (2016) yang memberikan hasil bahwa capital adequacy ratio tidak berpengaruh terhadap financing to deposit ratio bank syariah.

\section{Pengaruh Pembiayaan Musyarakah Terhadap Financing to Deposit Ratio}

Variabel pembiayaan musyarakah (X2) memiliki nilai t 0,116 dengan tingkat signifikansi 0,908 lebih besar dari taraf signifikansi 0,05 (5\%). Hal ini menunjukkan bahwa pembiayaan musyarakah tidak berpengaruh signifikan terhadap fiancing to deposit ratio. Dengan demikian hipotesis ketiga $(\mathrm{H} 3)$ ditolak. Hasil ini menunjukkan bahwa meski tidak berpengaruh secara signifikan tetapi pembiayaan musyarakah berjalan searah dengan financing to deposit ratio.

Penenlitian ini sejalan dengan hasil penelitian Dinna Nurhadiyanti (2014) yang menyatakan bahwa Pembiayaan Musyarakah tidak berpengaruh secara signifikan terhadap financing to deposit Ratio.Tetapi penelitian ini berbeda dengan penelitian Elza Mauduhatul Zahroh (2012) yang menyatakan bahwa pembiayaan bagi hasil musyarakah berpengaruh tidak signifikan terhadap financing to deposit ratio (FDR), hal tersebut menjelaskan bahwa pembiayaan musyarakah memiliki hubungan dengan financing to deposit ratio meski tidak signifikan. Dengan hasil penelitian tersebut maka mengindikasikan bahwa apabila pembiayaan musyarakah meningkat maka financing to deposit ratio juga meningkat. 


\section{Pengaruh tingkat margin murabahah terhadap financing to deposit ratio}

Variabel tingkat margin murabahah memiliki nilai t 0,928 dengan tingkat signifikansi 0,361 lebih besar dari taraf signifikansi $0,05(5 \%)$. Hal ini menunjukkan bahwa tingkat margin murabahah tidak berpengaruh signifikan terhadap fiancing to deposit ratio. Dengan demikian hipotesis ketiga (H4) ditolak. Hasil ini menunjukkan bahwa meski tidak berpengaruh secara signifikan tetapi tingkat margin murabahah dapat berpengaruh besar terhadap minat nasabah dalam memberikan dananya kepada pihak bank yang secara tidak langsung bisa saja dapat mempengaruhi tingkat financing to deposit ratio. Penelitian ini tidak sejalan dengan hasil penelitian yang dilakukan oleh Nareswari Saputro (2014) yang menyatakan bahwa tingkat margin murabahah mempengaruhi financing to deposit ratio perbankan syariah di Indonesia periode 2010 s.d 2012.

Dengan hasil penelitian tersebut maka mengindikasikan bahwa apabila tingkat marjin keuntungan lebih rendah dari pada rata-rata suku bunga perbankan nasional, maka pembiayaan syariah semakin kompetitif sehingga jumlah pembiayaan yang disalurkan oleh bank syariah akan meningkat. Pengaruh ini terjadi karena tingkat marjin berhubungan dengan minat masyarakat untuk melakukan pembiayaan di bank syariah. Ketika tingkat marjin meningkat maka minat masyarakat untuk bekerjasama semakin berkurang, hal tersebut terjadi karena masyarakat dihadapkan dengan jumlah marjin yang tidak sesuai dengan keinginan mereka, sehingga tingkat marjin yang tinggi ini akan memberatkan nasabah untuk beralih ke bank lain yang lebih menguntungkan.

\section{Kesimpulan, Keterbatasan, dan Saran Kesimpulan}

Berdasarkan pembahasan penelitian yang telah dikemukakan sebelumnya, dapat disimpulkan bahwa:

1) Capital adequacy ratio, pembiayaan musyarakah dan tingkat marginmurabah ah bersama-sama berpengaruh signifikaan terhadap financing to deposit ratio pada bank umum syariah diindonesia.

2) Capital adequacy ratio berpengaruh si gnifikan terhadap financing to deposit ratio pada bank umum syariah, dengan meningkatnya tingkat capital adequacy ratio, maka hal tersebut membuktikan bank mampu dalam menanggung risiko kerugian yang mungkin dialami.

3) Pengaruh Musyarakah tidak berpengaruh terhadap financing to deposit ratio pada bank umum syariah di Indonesia, hal ini tersebut mengindikasikan bahwa pembiyaan musyarakah tidak berpengaruh secara langsung terhadap financing to deposit Ratio, tetapi pembiayaan musyarakah berjalan searah dengan financing to deposit ratio.

4) Tingkat margin murabahah tidak berpengaruh signifikan terhadap financing to deposit ratio Hasil ini menunjukkan bahwa meski tidak berpengaruh secara signifikan tetapi tingkat margin murabahah dapat berpengaruh besar terhadap minat nasabah dalam memberikan dananya kepada pihak bank yang secara tidak langsung bisa saja dapat mempengaruhi tingkat financing to deposit ratio.

\section{Keterbatasan}

Penelitian ini mempunyai keterbatasanketerbatasan yang dapat dijadikan bahan pertimbangan bagi peneliti selanjutnya sehingga diperoleh hasil yang lebih baik lagi yaitu antara lain:

1) pada penelitian ini horizon waktu penelitiannya hanya tiga tahun, sehingga data yang dikumpulkan tidak sepenuhnya tercantum dalam laporan keuangan

2) populasi penelitian hanya pada bank umum syariah saja.

\section{Saran}

\section{Saran Akademis}

Sebaiknya untuk penelitian selanjutnya lebih memperluas objek penelitian, sehingga hasil yang didapat akan lebih efisien, dikarenakan tidak adanya keterbatasan data. Dan pada periode penelitian sebaiknya lebih dari 3 periode agar data yang diperoleh lebih akurat untuk menunjang pengujian setelahnya terkait variabel yang dipilih, sehingga dapat dibandingkan dengan penelitian-penelitian sebelumnya.

\section{Saran Praktis}

1) Bagi perbankan syariah khususnya bank umum syariah sebaiknya lebih informatif 
dalam melampirkan laporan keuangan, sehingga memudahkan pembaca dalam menganalisis laporan keuangan tersebut serta lebih memperhatikan pembiayaan yang menjadi pokok utama sumber penghasilan bank syariah.

2) Bagi investor diharapkan mampu berkontribusi lebih dalam untuk memberikan pendanaan yang lebih baik agar dapat terciptanya perputaran uang yang lebih efisien.

\section{Daftar Pustaka}

Amriani, Nurnaningsih. 2012. Mediasi alternatif Penyelesaian Sengketa Perdata di Pengadilan. Jakarta: Rajawali Pers.

An-Nabhani, Taqiyyuddin.1996. Membangun Ekonomi Alternatif Perspektif Islam.Surabaya: Risalah Gusti.

Antonio, Muhammad Syafi'i. 2005. Bank Syariah Dari Teori ke Praktek. Jakarta: Gema Insani bekerjasama dengan Tazkia Cendekia.

Ariyani, Dinna. 2014. Analisis Pengaruh Pertumbuhan Pembiayaan Murabahah, Bagi Hasil, dan Pinjaman Qardh Terhadap Pertumbuhan Laba Bersih pada Bank Syariah Periode Triwulan I 2011 sampai Triwulan IV 2013. Artikel Mahasiswa.

Ascarya. 2011. Akad \& Produk Bank Syariah. Jakarta: PT. Raja Grafindo Persada

Aziz Yahya, Abdul.2011. Analisis Pengaruh Variabel Makro Dan Mikro Terhadap Financing To Deposit Ratio (FDR) Perbankan Syariah.Makalah disajikan dalam Seminar Ekonomi Islam.Tazkia University College of Islamic Economics. Bogor.

Bank Indonesia, 1993. Surat Edaran No.26/5BPPP. Jakarta.

Billy Arma Pratama. 2010. Analisis Faktor-Faktor Yang Mempengaruhi Kebijakan Penyaluran Kredit Perbankan ( Studi Pada Bank Umum di Indonesia Periode tahun 2005- 2009). Semarang : Universitas Dipenogoro, 397-403. ISSN 19079958.

Delsy Setiawati Ratu Edo dan Ni Luh Putu Wiagustini. 2014. "Pengaruh Dana Pihak Ketiga. Non Performing Loan, dan Capital adequacy Ratio terhadap Loan Deposit Ratio dan Return On
Assets Pada SektorPerbankan Di Bursa Efek Indonesia”. E-Jurnal Ekonomi Dan Bisnis. Universitas Udayana.

Dendawijaya, Lukman. 2005. Manajemen Perbankan. Jakarta: Penerbit Ghalia Indonesia.

Dinna Nurhadiyanti, 2014. Pengaruh Pembiayaan Musyarakah terhadap Financing to Deposit Ratio pada PT. Bank Pembiayaan Rakyat Syariah (BPRS) Alwadi'ah Tasikmalaya. Diploma thesis, UIN Sunan Gunung Djati Bandung.

Elza Mauduhatul Zahroh, 2012. Pengaruh Pembiayaan Bagi Hasil, Non Performing Financing (NPF) dan Tingkat Inflasi Terhadap Financing To Deposit Ratio (FDR) Pada PT. Muamalat Indonesia, Tbk. Diploma IV Tugas Akhir. Politeknik Negeri Bandung.

Ervani, Eva. 2010. Analisis Pengaruh Capital Adequacy Ratio, Loan to Deposit Ratio, dan Biaya Operasional Bank Terhadap Profitabilitas Bank go public di Indonesia Periode 2000-2007. Volume 3 Nomor 2.

Ghozali, Imam. 2013. Aplikasi Analisis Multivariate Dengan Program IBM SPSS 21 Update PLS Regresi. Semarang : Badan Penerbit Universitas Diponegoro.

Ilna, Nabilla. 2015. "Faktor-Faktor yang Mempengaruhi Audit Delay pada Pemerintah Daerah Se-Indonesia". Skripsi. Bandar Lampung: Fakultas Ekonomi dan Bisnis Universitas Lampung.

Jihad dan Hosen, M Nadratauzaman.2009. Faktorfaktor yang Mempengaruhi Permintaan Pembiayaan Murabahah Bank Syariah di Indonesia (Periode Januari 2004 - Desember 2008) '.Jakarta : UIN Syarif hidayatullah.

Karim, Adiwarman A. 2007. Bank Islam: Analisis Fiqih dan Keuangan. Edisi Ketiga. Jakarta: PT. Raja Grafindo Persada.

Karim, Adiwarman. 2010. Bank Islam : Analisis Fiqih dan Keuangan. Jakarta : RajaGrafindo Persada.

Laporan Tahunan 2013. Retrieved from Bank Indonesia: http://www.bi.go.id/id/publikasi/la porantahunan/perekonomian/Page s/LPI_2013.aspx, diakses 09 Januari 2017

Laporan Tahunan 2014. Retrieved from Bank Indonesia: http://www.bi.go.id/id/publikasi/la 
porantahunan/perekonomian/Page

s/LPI_2014.aspx, diakses 09 Januari 2017

Laporan Tahunan 2015. (n.d.). Retrieved from Bank

Indonesia: http://www.bi.go.id/id/publikasi/la porantahunan/perekonomian/Page

s/LPI_2015.aspx, diakses 09 Januari 2017

Muhammad. 2005. Manajemen Pembiayaan Bank Syariah. Yogyakarta: UPP AMP YKPN.

Nareswari Saputro. 2014. "Pengaruh Tingkat Marjin Murabahah Terhadap Financing To Deposit Ratio dan Non Performing Financing (Study Pada Bank Syariah Di Indonesia Periode 20102012). Surabaya : Universitas Airlangga

Peraturan Bank Indonesia Nomor 10/15/PBI/2008 tentang Kewajiban Penyediaan Modal Minimum Bank Umum, Lembaran Negara Republik Indonesia Tahun 2008 Nomor 135, Tambahan Lembaran Negara Republik Indonesia Nomor 4895 .

Prihatiningsih. 2012. Dinamika Financing To Deposit Ratio

Rivai, Veithzal dan Arviyan Arifin. 2010. Islamic Banking: Sistem Bank Islam Bukan Hanya Solusi dalam Menghadapi Berbagai Persoalan Perbankan \& Ekonomi Global. Jakarta: Bumi Aksara.

Ruslim. 2012. “Analisis Pengaruh Capital Adequancy Ratio (CAR), Non Performing Loan (NPL), dan Loan to Deposit Ratio (LDR) Terhadap Return On Asset (ROA) Pada Bank Umum Syariah Yang Terdaftar Di Bank Indonesia

Romadhoni Eka Nugraha. 2014. "Analisis Pengaruh Capital Adequacy Ratio (Car), Non Performing Loan (Npl), Biaya Operasional Pendapatan Operasional (Bopo), Return On Asset (Roa), Dan Net Interest Margin (Nim) TerhadapLoan To Deposit Ratio (Ldr) (Studi Empiris Pada
Perbankan Syraiah Di Indonesia Periode 20102012). Surakarta : Universitas Muhammadiyah.

Sekaran, Uma dan Bougie, Roger. 2013. Research Methods for Business. United Kingdom: Jhon Wiley \& Sons Ltd.

Sri Handayani . 2016. "Pengaruh Capital Adequacy Ratio (Car), Beban Operasional Pendapatan Operasional (Bopo), Return On Asset (Roa) Dan Net Interest Margin (Nim) Terhadap Financing Deposit Ratio (Fdr) (Studi Pada PT. Bprs Bhakti Sumekar Sumenep Periode 2011-2015). Pamekasan. STAIN.

Sudarsono Heri (2008), Bank \& Lembaga Keuangan Syari'ah. Yogyakarta: Ekonisia. Cetakan ke- 2

Sugiyono. 2010. MetodePenelitian Kuantitatif Kualitatif \& RND. Bandung : Alfabeta

Sugiyono. 2011. Metode Penelitian Kuantitatif Kualitatif Dan $R \& D$. Bandung : Alfabeta.

Umam, Khaerul. 2013. Manajemen Perbankan Syariah. Bandung: Pustaka Setia

Undang-Undang Republik Indonesia Nomor 21 Tahun 2008 Tentang Perbankan Syariah

Wahyono Teguh. 2005. Sistem Informasi: Konsep Dasar, Analisis Desain dan Implementasi Jakarta : Graha Ilmu

Widiantara. Arlan. 2013. Pengertian Loan to Debt Ratio (LDR). http://arlan widiantara. blogspot.com/201304/p engertian-loan-todeposit-ratio-

ldr.html?search=profitabilitas\#uds- searchresult.

Yosep Murdiyono. 2013. "Faktor-Faktor Yang Mempengaruhi Financing To Deposit Ratio Bank Syariah Tahun 2008 - 2012. Yogyakarta :UIN Sunan Kalijaga 


\section{Lampiran 1}

Pengujian Hipotesis

Tabel 1

Statistik Deskriptif

Hasil Uji Signifikansi Parameter Individual

Descriptive Statistics

\begin{tabular}{|l|r|r|r|r|r|}
\hline & \multicolumn{1}{|c|}{ N } & Minimum & Maximum & \multicolumn{1}{c|}{ Mean } & \multicolumn{1}{c|}{ Std. Deviation } \\
\hline FDR & 33 & 81,99 & 157,77 & 96,9512 & 16,39420 \\
CAR & 33 & 11,10 & 59,61 & 20,5891 & 10,99910 \\
PMUSYARAKAH & 33 & 5,87 & 53,37 & 24,7676 & 11,93467 \\
TMMURABAHAH & 33 & 10,37 & 47,38 & 26,2588 & 9,71186 \\
\hline
\end{tabular}

b. Dependent Variable: FDR

Tabulasi Data Penelitian

Tabel 2

Capital Adequacy Ratio Bank Umum Syariah di Indonesia

Periode 2013 s.d 2015

\begin{tabular}{|l|c|c|c|}
\hline \multicolumn{1}{|c|}{ Nama Bank } & $\mathbf{2 0 1 3}$ & $\mathbf{2 0 1 4}$ & $\mathbf{2 0 1 5}$ \\
\hline Bank Muamalat Indonesia & 17,55 & 13,91 & 12,36 \\
\hline Bank SyariahMandiri & 14,10 & 14,76 & 12,85 \\
\hline Bank Mega Syariah & 12,99 & 18,82 & 18,74 \\
\hline Bank BukopinSyariah & 11,10 & 14,80 & 16,31 \\
\hline BRI Syariah & 14,49 & 12,89 & 13,94 \\
\hline Bank PaninSyariah & 20,83 & 25,69 & 20,30 \\
\hline Bank JabarBantenSyariah & 17,99 & 15,83 & 22,53 \\
\hline Bank Victoria Syariah & 18,40 & 15,27 & 16,14 \\
\hline BNI Syariah & 16,54 & 18,43 & 15,48 \\
\hline BCA Syariah & 22,35 & 29,6 & 34,3 \\
\hline MaybankSyariah & 59,61 & 52,14 & 38,40 \\
\hline
\end{tabular}


Tabel 3

Pembiayaan Musyarakah Bank Umum Syariah di Indonesia

Periode 2013 s.d 2015

\begin{tabular}{|l|c|c|c|}
\hline \multicolumn{1}{|c|}{ Nama Bank } & $\mathbf{2 0 1 3}$ & $\mathbf{2 0 1 4}$ & $\mathbf{2 0 1 5}$ \\
\hline Bank Muamalat Indonesia & 34,76 & 30,98 & 30,93 \\
\hline Bank SyariahMandiri & 14,54 & 15,56 & 14,45 \\
\hline Bank Mega Syariah & 20,15 & 51,36 & 11,6 \\
\hline Bank BukopinSyariah & 21,94 & 25,93 & 24,54 \\
\hline BRI Syariah & 18,13 & 21,12 & 21,3 \\
\hline Bank PaninSyariah & 17,34 & 53,26 & 23,01 \\
\hline Bank JabarBantenSyariah & 22,74 & 15,26 & 13,73 \\
\hline Bank Victoria Syariah & 20,77 & 45,05 & 53,37 \\
\hline BNI Syariah & 25,46 & 5,87 & 7,18 \\
\hline BCA Syariah & 27,52 & 28,38 & 18,09 \\
\hline MaybankSyariah & 30 & 24,55 & 28,46 \\
\hline
\end{tabular}

Tabel 4

Tingkat Margin Murabahah Bank Umum Syariah di Indonesia

Periode 2013 s.d 2015

\begin{tabular}{|l|c|c|c|}
\hline \multicolumn{1}{|c|}{ Nama Bank } & $\mathbf{2 0 1 3}$ & $\mathbf{2 0 1 4}$ & $\mathbf{2 0 1 5}$ \\
\hline Bank Muamalat Indonesia & 19,29 & 25,76 & 25,01 \\
\hline Bank SyariahMandiri & 11,36 & 11,48 & 30,65 \\
\hline Bank Mega Syariah & 33,79 & 20,64 & 18,01 \\
\hline Bank BukopinSyariah & 35,41 & 26,06 & 26,62 \\
\hline BRI Syariah & 11,12 & 28,91 & 28,9 \\
\hline Bank PaninSyariah & 11,49 & 10,37 & 11,46 \\
\hline Bank JabarBantenSyariah & 47,38 & 38,88 & 42,42 \\
\hline Bank Victoria Syariah & 38,01 & 30,51 & 29,49 \\
\hline BNI Syariah & 29,16 & 37,73 & 38,06 \\
\hline BCA Syariah & 23,7 & 24,6 & 24,86 \\
\hline MaybankSyariah & 23,23 & 27,15 & 25,03 \\
\hline
\end{tabular}


Tabel 5

Financing to Deposit Ratio Bank Umum Syariah di Indonesia

Periode 2013 s.d 2015

\begin{tabular}{|l|c|c|c|}
\hline \multicolumn{1}{|c|}{ Nama Bank } & $\mathbf{2 0 1 3}$ & $\mathbf{2 0 1 4}$ & $\mathbf{2 0 1 5}$ \\
\hline Bank Muamalat Indonesia & 99,99 & 84,14 & 90,30 \\
\hline Bank SyariahMandiri & 89,37 & 82,13 & 81,99 \\
\hline Bank Mega Syariah & 93,37 & 93,61 & 98,49 \\
\hline Bank BukopinSyariah & 100,29 & 92,89 & 90,56 \\
\hline BRI Syariah & 102,70 & 93,90 & 84,16 \\
\hline Bank PaninSyariah & 90,40 & 94,04 & 96,43 \\
\hline Bank JabarBantenSyariah & 97,40 & 93,69 & 104,75 \\
\hline Bank Victoria Syariah & 84,65 & 95,19 & 95,29 \\
\hline BNI Syariah & 97,86 & 92,60 & 91,94 \\
\hline BCA Syariah & 83,48 & 91,2 & 91,4 \\
\hline MaybankSyariah & 152,87 & 157,77 & 110,54 \\
\hline
\end{tabular}

Gambar 2.1

Model Penelitian

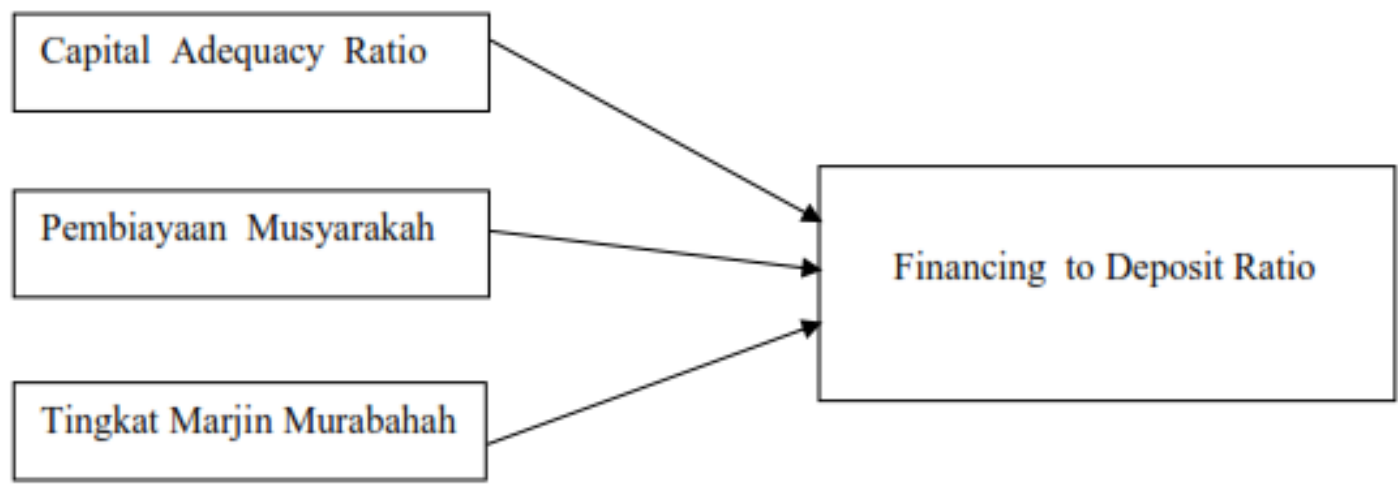

Adapun persamaannya sebagai berikut:

$Y=\alpha+\beta_{1} X_{1}+\beta_{2} X_{2}+\beta_{3} X_{3}+\varepsilon$

\section{Keterangan :}

Y : Financing to Deposit Ratio

$\alpha \quad$ : Konstanta 
$\beta \quad$ : Koefisien Regresi

X1 : Capital Adequacy Ratio

X2 : Pembiayaan Musyarakah

X3 : Tingkat Marjin Murabahah

$\varepsilon \quad:$ Standar Error 